\title{
Corrigendum: Reisverslag in twee stemme en agt gedigte
}

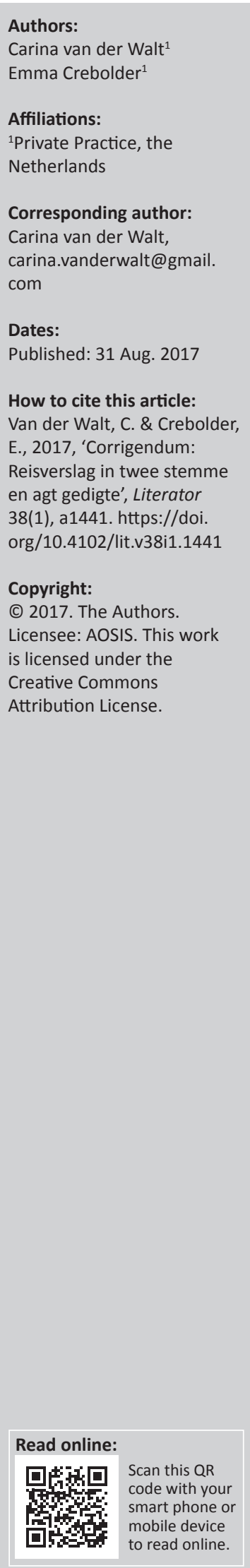

Die gepubliseerde artikel maak verkeerdelik melding dat Christo Coetzee 'se styl het dieselfde "broeierigheid" en soms seksuele blatantheid wat van die Brasiliaanse oubasie Drummond de Andrade tussen sy tagtigste en sy vyf-en-tagtigste lewensjaar ' $n$ besondere vitale digterlike ster gemaak het' (bl. 4) waar dit na Christo van Staden moes verwys.

Die outeurs vra omverskoning dat hule Christo van Staden se van, per abuis as Coetzee aangedui het.

Die paragraaf op bl. 4 word dus verwang en moet lees:

‘Ek maak onder andere kennis met Corné Coetzee, wie se digstyl vir beide my én Emma baie aan ons gesamentlike Nederlandse digtersvriendin Kreek Daey Ouwens herinner. Wanneer verskyn haar debuutbundel? Christo van Staden se styl het dieselfde "broeierigheid" en soms seksuele blatantheid wat van die Brasiliaanse oubasie Drummond de Andrade tussen sy tagtigste en sy vyf-en-tagtigste lewensjaar 'n besondere vitale digterlike ster gemaak het. Ook René Bohnen, Hans Pienaar en Jo Prins se gedigte het ons in Melville verras. Inderdaad, "zeer divers".' 